\title{
KEARIFAN LOKAL PESANTREN SEBAGAI BANGUNAN IDEAL MODERASI ISLAM MASYARAKAT MADURA
}

\author{
Zainuddin Syarif \\ Institut Agama Islam Negeri Madura, Indonesia \\ E-mail: doktorzainuddinsyarif@gmail.com \\ Abd Hannan \\ Institut Agama Islam Negeri Madura, Indonesia \\ E-mail: hannan.taufiqi@gmail.com
}

\begin{abstract}
In many social studies, Madura is known as an archipelago with its various local wisdoms, embodied in the socio-religious systems and structures of pesantren. Pesantren is a social system and structure that contains local values which have great influence especially on the formation of Islamic traditions among the Madurese community. This study employs a qualitative approach with a library method, combined with the perspective of the sociology of religion. Theoretically, this study is aimed to enrich the scholarship on social and religious studies, and practically to build Islamic culture that upholds the values of moderatism. The findings of this study contain an in-depth description of local wisdom values of pesantren in Madura, their role in, and influence on, the formation of Islamic moderatism among the Madurese community.
\end{abstract}

Keywords: Pesantren; local wisdom; Islamic moderation.

\section{Pendahuluan}

Secara sosiologis, harus diakui bahwa kajian tentang realitas keagamaan masyarakat Madura sejauh ini menjadi salah satu tema yang tidak saja penting, tetapi juga menarik. Disebut penting karena ia pasti membicarakan satu bangunan sistem sosial yang kental dengan nilai-nilai tradisional. ${ }^{1}$ Term tradisional di sini merujuk pada kehidupan masyarakat Madura, yang dalam tradisi

\footnotetext{
1 Tatik Hidayati, "Perempuan Madura antara Tradisi dan Industrialisasi", Karsa: Journal of Social and Islamic Culture, Vol. 16, No. 2 (2009), 66.
} 
atau kebudayaannya senantiasa menjunjung tinggi kreativitas lokal. Salah satu kreativitas lokal yang dimaksud adalah budaya hirarki, seperti patriarki, feodalisme, dan sejenisnya, yang demikian subur dalam sistem dan struktur sosial masyarakat Madura. kondisi tersebut tercermin jelas dalam standar kepatuhan yang dikenal dalam peribahasa Madura bhuppa' bhabbhu' gburu rato. ${ }^{2}$

Sementara disebut menarik karena ketika membicarakan realitas keagamaan masyarakat Madura, maka akan terpampang satu ciri lokalitas yang berkelit-kelindan dengan religiusitas. Beberapa simbol dan lembaga keagamaan, seperti kiai, pesantren, dan ormas keislaman Nahdlatul Ulama (NU), merupakan unsur keagamaan yang sejauh ini melekat kuat dalam tradisi, sistem, dan struktur sosial masyarakat Madura. Hal menarik dari hubungan pola keagamaan masyarakat Madura dengan keberadaan pesantren, kiai, dan NU, terletak pada sisi ikatan emosional yang begitu kuat. ${ }^{3}$ Dapat dikata, pesantren, kiai, dan NU adalah tiga unsur keagamaan yang memiliki peran dan pengaruh signifikan. Tidak saja dalam hal keagamaan, peran dan pengaruh tersebut juga tampak pada aspek sosial-budaya, mulai pendidikan hingga ke ranah paling tabu sekalipun, seperti politik.

Dalam lingkup yang luas, studi tentang Madura sesungguhnya sudah sering dilakukan, baik dari perspektif kebudayaan, sosiologi, politik, ekonomi, dan lintas keilmuan lainnya. Beberapa studi yang relevan untuk disebutkan di sini antara lain adalah studi tentang kebudayaan masyarakat Madura oleh Kuntowijoyo, ${ }^{4}$ realitas politik

\footnotetext{
2 Menurut peribahasa ini, orang Madura pertama harus patuh pada kedua orang tua (bhuppa' bhabbhu'), lalu guru (ghuru), dan terakhir pada pemimpin (rato). Abd Hannan, "Agama, Kekerasan, dan Kontestasi Politik Elektoral: Penggunaan Simbol Keagamaan Kiai dan Kekuasaan Blater dalam Pertarungan Politik Lokal Madura", Jurnal Sosiologi Agama, Vol. 12, No. 2 (2018), 213.

3 Abd Hannan, "Fanatisme Komunitas Pesantren NU Miftahul Ulum dan Stigma Sosial pada Muhammadiyah di Kabupaten Pamekasan" (Tesis-Universitas Airlangga Surabaya, 2017), 345.

4 Menurut Kuntowijoyo, Madura merupakan satu wilayah unik karena mempunyai bentukan ekologi yang khas yang membentuk pola pemukiman yang relatif terpencar, sehingga masyarakat Madura memiliki kecenderungan melakukan migrasi ke luar daerah. Kuntowijoyo, Perubahan Sosial dalam Masyarakat Agraris Madura 1850-1940, terj. Mahmoed Effendhie (Yogyakarta: Mata Bangsa, 2002), 67.
} 
Madura oleh Rozaki ${ }^{5}$ dan Salam, ${ }^{6}$ sejarah dan struktur sosial masyarakat pesantren Madura oleh Abdullah, ${ }^{7}$ dan tentang keterkaitan antara kearifan lokal dan sastra di Madura oleh Sadik. ${ }^{8}$ Berdasarkan beberapa studi di atas, tampak bahwa realitas sosiokultur masyarakat Madura begitu lekat dengan budaya hirarki, terutama yang berpusat pada simbol dan struktur keagamaan seperti kiai, pesantren, dan ormas Islam. Unsur-unsur kekuasaan dan keagamaan yang terbangun dalam nama besar dan kharisma kiai, pesantren, dan NU, dalam batasan-batasan tertentu, nyatanya tidak saja mengambil tempat dalam proses distribusi kekuasaan, tatapi turut pula memengaruhi konstruksi sosio-kultural masyarakat Madura secara menyeluruh. Dalam kaitan ini, dapat dikatakan bahwa sistem dan struktur masyarakat Madura mencerminkan adanya bangunan budaya hirarki yang kemudian menjadi dasar bagi konstruksi kebudayaaan masyarakat. Pada perkembangannya, hal ini menjadi identitas kehidupan mereka. Sistem kebudayaan masyarakat Madura yang menjunjung tinggi simbol atau lambang keagamaan, seperti kepada kiai dan pesantren, merupakan perwujudan nilai kearifan lokal. Karena sifatnya yang lokal inilah, Nurcholish Madjid menyebut pesantren sebagai indigenous yang tumbuh-berkembang dari realitas keaslian daerah. ${ }^{9}$

\footnotetext{
${ }^{5}$ Rozaki melihat Madura sebagai sebuah realitas politik yang berada di bawah kendali dua rezim kembar, yakni kiai dan blater. Abdur Rozaki, Menabur Kharisma Menuai Kuasa; Kiprah Kiai dan Blater sebagai Rezim Kembar di Madura (Yogyakarta: Pustaka Marwa, 2004), 21.

${ }^{6}$ Moh. Ishaq Abd Salam, "Reproduksi Kekuasaan Kiai; Penggunaan Sarana Ideologi dan Kekuasaan dalam Pemilukada Bangkalan" (Tesis--Universitas Airlangga Surabaya, 2015), 56.

7 Abdullah berkesimpulan bahwa selain sebagai lembaga keagamaan, keberadaan pesantren di tengah masyarakat Madura juga representasi jati diri dan kepribadian masyarakat setempat yang kental dengan atmosfer keislaman yang moderat, ramah, dan menjunjung tinggi adat dan tradisi lokal. Said Abdullah, Pesantren; Jati Diri dan Pencerahan Masyarakat, Cet. I (Sumenep: Said Abdullah Istitute Publishing, 2010), 34.

8 Sadik menyimpulkan bahwa keberadaan sastra di Madura, baik yang berupa syair, puisi, maupun kata-kata bijak, semuanya mengandung seperangkat nilai dan nesihat hidup yang mencerminkan tatanan kehidupan masyarakat Madura dalam segala aspek, termasuk di dalamnya aspek sosial-keagamaan. A. Sulaiman Sadik, "Kearifan Lokal dalam Sastra Madura dan Aplikasinya dalam Kehidupan Sehari-Hari," Okara: Jurnal Bahasa dan Sastra, Vol. 1, No. 6 (2011), 87 dan 100.

${ }^{9}$ Nurcholish Madjid, Bilik-Bilik Pesantren: Sebuab Potret Perjalanan, Cet. I (Jakarta: PT. Dian Rakyat, 1997), 3.
} 
Berangkat dari kerangka pikir di atas, artikel ini berkepentingan khusus untuk mengkaji dan mendeskripsikan secara mendalam berbagai hal yang berkenaan dengan eksistensi pesantren di Madura sebagai bagian dari kearifan lokal, serta peran strategisnya dalam membentuk bangunan ideal moderasi Islam di kalangan masyarakat Madura. Beberapa persoalan krusial yang selama ini berkenaan dengan komunitas pesantren di Madura, seperti sistem budaya, pembelajaran, tradisi keagamaan, ${ }^{10}$ dan sistem sosial di lingkungan pesantren, tidak akan luput dari beberapa pembahasan dalam artikel ini. Lewat studi kepustakaan, artikel ini menelusuri data yang difokuskan pada tiga tema besar: komunitas pesantren, kearifan lokal, dan moderasi Islam. Pada akhirnya, artikel ini menemukan bahwa pesantren sebagai representasi bagi hubungan dialogis lokalitas dan religiusitas, yang disokong peran strategis kiai dan afiliasinya dengan NU, cukup mampu untuk memainkan peran sebagai corong bagi upaya perwujudan moderasi agama yang saat ini diyakini sebagai kosep berislam yang relevan dalam konteks keindonesiaan.

\section{Islam Moderat dan Kearifan Lokal; Pembacaan Konseptual}

Secara etimologis, berdasarkan Kamus Besar Bahasa Indonesia $(K B B I)$, "moderat" mempunyai arti sikap yang senantiasa menghindari perilaku atau pengungkapan yang ekstrem. Kata kunci yang perlu digarisbawahi di sini adalah 'menghindari', 'perilaku atau pengungkapan', dan 'ekstrem'. Ekstrem berarti paling ujung, paling keras, fanatik, atau hal yang keterlaluan. Jika merujuk pada definisi ini, maka Islam moderat mengisyaratkan usaha sadar menjauhkan cara keberagamaan (Islam) yang jauh dari perilaku kasar, keras, dan keterlaluan, baik itu dalam bersikap, berpikir, berucap, ataupun bertindak. Sederhananya, moderat dalam pengertian ini menitikberatkan pada penghiasan sikap dan perilaku diri yang halus. Lebih jauh, Khaled Abou El Fadl menggolongkan kata moderat sebagai lawan kata dari puritan, di mana puritan didefinisikan sebagai satu ciri gerakan Islamisme yang berorientasi kekuasaan yang menyerukan kembali kepada identitas Islam

10 I Made Wiratha, Metodologi Penetilian Sosial Ekonomi (Yogyakarta: CV. Andi Offset, 2006), 23. 
otentik melalui penerapan sharīah Islam. ${ }^{11}$ Dengan demikian, bisa dikata bahwa Islam moderat adalah wujud mediasi antara dua tarikan Islam ekstrem, yakni Islam kanan dan Islam kiri, yang tidak saling menyalahkan, tidak menyatakan paling benar sendiri, dan bersedia berdialog, sehingga tercermin bahwa perbedaan itu benarbenar rahmat. ${ }^{12}$

Dalam bahasa Inggris, term moderat berasal kata moderate, yang artinya average in amount, intensity, quality, etc.; not extreme (rata-rata dalam jumlah, intensitas, kualitas, dan lain-lain; tidak ekstrem); of or having (political) opinions that are not extreme (pandangan politik yang tidak ekstrem); keeping or kept within limits that are not excessive (menjaga dalam batas-batas yang tidak berlebihan). ${ }^{13}$ Adapun dalam bahasa Arab, moderat senantiasa diselaraskan dengan kata al-tawassut (tengah), al-ítidāl (adil), dan semacamnya. Dalam banyak kesempatan, sejumlah pemikir Islam seringkali menggunakan istilah tersebut untuk menggolongkan satu sikap atau perilaku keagamaan yang tidak mengedepankan pendekatan kekerasan, terutama menyangkut ihwal permasalahan keagamaan yang bersentuhan dengan wilayah teologis. ${ }^{14}$ Sikap tawassut merupakan representasi pola keberagamaan yang di satu sisi tidak memiliki keberpihakan pada kelompok Islam kanan, dan di sisi lain juga tidak condong ke kelompok kiri. Karena sikap semacam inilah, oleh kebanyakan penganut Islam normatif, kelompok moderat dianggap tidak menggambarkan semangat keberagamaan (ghirah diniyab) yang kuat. ${ }^{15}$ Di banyak negara, term tawassut adalah satu karakteristik keislaman yang mempunyai kedekatan begitu kuat

11 Rusli, "Gagasan Khaled Abu Fadl tentang Islam Moderat versus Islam Puritan: Perspektif Sosiologi Pengetahuan”, Ilmu Ushuluddin, Vol. 8, No. 1 (2009), 116.

12 Asep Abdurrohman, "Eksistensi Islam Moderat dalam Perspektif Islam", Rausyan Fikr, Vol. 14, No. 1 (2018), 29.

13 Tim Penyusun, Oxford Advanced Learner's Dictionary (Oxford: Oxford University Press, 1994), 798.

14 Masdar Hilmy, "Quo-Vadis Islam Moderat Indonesia?: Menimbang Kembali Modernisme Nahdlatul Ulama dan Muhammadiyah", Miqot: Jurnal Ilmu-ilmu Keislaman, Vol. 37, No. 2 (Juli-Desember 2012), 264.

15 M.A. Muqtedar Khan, "Islamic Democracy and Moderate Muslims: The Straight Path Runs through the Middle", American Journal of Islamic Social Sciences, Vol. 22, No. 3 (2005), 40. 
dengan nilai-nilai lokalitas, baik dalam hal kebudayaan maupun adat istiadat.

Adapun dalam pengertian terminologisnya, Masdar Hilmy menggarisbawahi term Islam moderat sebagai istilah yang merujuk pada mereka yang menolak pemberlakuan kekerasan sebagai garis ideologi dan perjuangannya. ${ }^{16}$ Penolakan kekerasan dalam aspek ideologi sama artinya dengan menjauhkan cara berpikir dan cara pandang diri dari setiap pola berpikir yang berorientasi pada kekerasan. Moderatisme dalam berideologi artinya menjunjung tinggi keluasan, kedalaman, dan keseimbangan dalam berpikir dan menalar. Menghindari pola pikir yang kaku, jumud, pembacaan dan penafsiran aspek-aspek teologis yang tekstual. Berideologi secara moderat adalah perwujudan pandangan sosial keagamaan kritis, sehingga pada gilirannya dapat menghindarkan individu dari pemikiran dan perilaku keagaman yang sempit. Perjuangan diri, baik dalam hal agama mupun politik, terletak pada kuatnya akar toleransi dan pluralitas sistem keyakinan dan kepercayaan. Ciri khas paling mendasar dari kesemuanya adalah kesediaan diri menerima dan hidup berdampingan dengan golongan atau kelompok keagaman di luar diri, dan pada batasan-batasan tertentu, juga sikap memiliki dan pandangan keagamaan yang mengakui atas kebenaran ajara-ajaran keagamaan di luar dirinya (inklusif). Karena kriterianya yang demikian, sejumlah kalangan seringkali menilai Muslim moderat sebagai kelompok yang proBarat. ${ }^{17}$

Terlepas dari pembacaan etimologis maupun terminologis di atas, secara umum term moderat memuat makna jalan tengah (third way). Jika Anthony Giddens mendudukkan istilah jalan tengah sebagai solusi atas tarikan dua binner mazhab politik global, antara sosialisme dan kapitalisme, maka Islam moderat adalah perwujudan jalan tengah di antara dua kutub ekstrem gerakan Islam kontemporer, yakni radikal dan liberal. Kelompok Islam radikal adalah satu wujud pemikiran dan gerakan Islam yang memuat pandangan fudamentalisme sektarian. Sedangkan Islam liberal adalah wajah kelompok keislaman yang mendasarkan dirinya pada teologi kapitalistik yang mereduksi pemikiran mereka pada semangat etika Protestan seperti yang diperkenalkan oleh Max

\footnotetext{
${ }^{16}$ Hilmy, "Quo-Vadis Islam Moderat", 263.

${ }^{17}$ Khan, "Islamic Democracy", 40.
} 
Weber. Dalam tradisi pemikiran keagamaan, kutub ekstrem seringkali didefinisikan sebagai al-ghulumw-Yūsuf al-Qarḍ̄̄wī sering menyebutnya sebagai al-mutatarrif_dan kutub moderat sering disebut sebagai al-wast yang berarti jalan tengah (middle-path atau middle-way). ${ }^{18}$

Adapun kearifan lokal, secara etimologis merupakan wujud kesatuan dari dua kata dasar, yaitu kearifan, dan lokal. "Kearifan" berasal dari kata dasar "arif", yang menurut $K B B I$ artinya bijaksana; cerdik pandai berilmu. ${ }^{19}$ Sementara "lokal" dalam pengertian $K B B I$ berarti setempat; terjadi (berlaku, ada, dsb.) di satu tempat saja, tidak merata. ${ }^{20}$ Dengan demikian, kearifan lokal adalah seperangkat nilai, kreativitas, atau pandangan yang memuat unsur kebijaksanaan, berkeadaban, dan berperadaban yang ada dan berlaku di suatu daerah tertentu.

Sedangkan dalam pengertian terminologisnya, kearifan lokal mengacu pada berbagai kekayaan alam-sosial yang tumbuh dan berkembang dalam sebuah masyarakat yang dipercaya dan diakui sebagai bagian penting yang mampu memperkuat kohesi sosial di antara warga masyrakat. ${ }^{21}$ Pengertian ini mengisyaratkan bahwa kearifan lokal hakikatnya muncul dan tumbuh dari kemampuan dan kreativitas masyarakat, yang kemudian terinternalisasi dalam kesadaran, pikiran, sikap, dan perilaku keseharian mereka. Konsep kohesi sosial dalam pembacaan ini mensyaratkan pada fungsi dan peran strategis kearifan lokal sebagai pembentuk integritas dan kesatuan masyarakat; menjauhkan masyarakat dari perpecahan dan disintegrasi sosial.

Menurut Mitchell, term kearifan lokal berasal dari sistem pengetahuan dan pemberdayaan nilai-nilai lokal, tradisi, dan adat. ${ }^{22}$ Sedangkan menurut Zakaria, kearifan lokal bisa dipahami sebagai pengetahuan kebudayaan yang ada dalam sistem dan struktur sosial masyarakat tertentu yang memuat serangkaian pengetahuan

18 Al-Wast diartikan oleh Hans Wehr sebagai middle-path, jalan tengah. Hans Wehr, Modern Written Arabic (Gottingen: Otto Harrassowitz Verlag, 1979), 1248.

${ }^{19}$ Departemen Pendidikan dan Kebudayaan, Kamus Besar Bahasa Indonesia, Cet. 2 (Balai Pustaka: Jakarta, 1999), 48.

${ }^{20}$ Ibid., 530.

${ }^{21}$ Abdullah, Pesantren, 7.

22 Arya Hadi Dharmawan, "Kearifan Lokal dalam Sistem Sosial Ekonomi Masyarakat Penenun Bugis-Wajo”, Mudra, Vol. 28, No. 2 (2013), 130. 
kebudayaan yang terdiri dari sejumlah pengetahuan kebudayaan, serta tata cara pengelolaan, pemberdayaan, dan pemanfaatan sumber daya alam-sosial secara lestari. ${ }^{23}$ Dalam kesempatan yang lain, kearifan lokal juga didefinisikan sebagai pengetahuan, gagasan, nilai, keterampilan, pengalaman, tingkah laku, dan kebiasaan adat yang dilakukan oleh masyarakat di wilayah tertentu. ${ }^{24}$ Dengan demikian, kearifan lokal sebagai bagian dari realitas masyarakat yang memiliki kompleksitas nilai, dalam batasan-batasan tertentu, memiliki fungsi sebagai strategi dan pandangan hidup untuk menjawab berbagai masalah dalam upaya pemenuhan kebutuhan masyarakat lokal terkait. Berkaitan dengan fungsinya, Sirtha menyebutkan bahwa kearifan lokal yang terdiri dari kebudayaan, tradisi, pengetahuan, kreasi, dan seperangkat nilai-nilai lokal lainnya memiliki fungsi sebagai (1) konservasi dan pelestarian sumber daya alam; (2) mengembangkan sumber daya manusia; (3) pengembangan kebudayaan dan ilmu pengetahuan; (4) petuah, kepercayaan, sastra, dan pandangan hidup. ${ }^{25}$

Dalam kaitan inilah, maka fungsi-fungsi kearifan lokal di atas, khususnya fungsi pengembangan kebudayaan, petuah, dan kepercayaan, sesunguhnya dapat dimanfaatkan sebagai instrumen pengembangan dan pembangunan sistem sosial dalam segala aspek, baik aspek pendidikan, aspek ekonomi, aspek politik, bahkan ke dalam aspek keagamaan sekalipun. Kearifan lokal dapat menjadi jawaban dari sekian strategi pengembangan dan pemberdayaan sistem sosial dan kebudayaan lokal yang selama ini mengalami tantangan cukup berat akibat proyek globalisasi. Dalam hal keagamaan, di tengah masifnya penyebaran paham-paham radikal, menyeruaknya ajaran Islam fundamentalis dan liberal, pandangan keagamaan berbasis kearifan lokal yang terpendam dan terutama banyak ditemukan dalam jati diri pesantren dapat diproyeksikan sebagai jalan moderasi di tengah dua kutub keislaman yang tarik-menarik, antara liberal dan radikal, dan antara Islam kanan dan Islam kiri.

\footnotetext{
23 Nur Arafah, "Pengetahuan Lokal Suku Moronene dalam Sistem Pertanian di Sulawesi Tenggara" (Tesis--Institut Pertanian Bogor, 2002), 231.

24 Beti Nur Hayati dan Muhammad Arif Fahrudin Alfana, "Kebijakan Kependudukan di Kabupaten Sleman Pascaberakhirnya MDGS", Natapraja: Jurnal Kajian Ilmu Administrasi Negara, Vol. 4, No. 2 (2016), 125.

${ }_{25}$ Sartini, "Menggali Kearifan Lokal Nusantara: Sebuah Kajian Filsafati", Jurnal Filsafat, Vol. 14, No. 2 (2004), 127.
} 
Dalam konteks keislaman Madura, cita-cita moderasi Islam melalui kearifan lokal tercermin jelas dalam produk keagamaan pesantren. Dalam kaitan ini, pesantren sebagai lembaga keislaman tradisional bukan saja berperan sebagai lembaga dakwah yang memiliki visi penyebaran ajaran Islam di Madura. Lebih dari itu, ia juga merupakan bagian dari bangunan sistem dan struktur keagamaan yang memiliki relevansi kuat dengan semangat kebudayaan nusantara. Semangat kebudayaan yang dimaksud dalam hal ini adalah yang menjunjung tinggi toleransi, kebhinnekaan, dan kemajemukan. Selain itu, kultur khas pesantren melalui kemampuan adaptasinya dengan tradisi dan kebudayaan masyarakat sekitar, sejauh ini telah terbukti memainkan peran dan fungsi strategis di segala aspek, tidak saja dalam sektor keagamaan, tetapi juga dalam hal menjaga stabilitas dan integrasi sosial masyarakat Madura secara menyeluruh.

\section{Madura dalam Perspektif Sosial-keagamaan}

Jika merujuk pada penjelasan Huub de Jonge, Madura sebagai daerah kepulauan dapat dibagi menjadi dua kutub besar, yakni Madura barat dan Madura timur. ${ }^{26}$ Madura barat adalah daerah yang berada di sisi barat. Dua daerah seperti Bangkalan dan Sampang adalah wilayah administratif yang masuk pada kutub ini. Sedangkan dua wilayah adminitratif lainnya, Pamekasan dan Sumenep, masuk dalam Madura kutub timur. Dengan pembagian ini, Huub de Jonge hendak menjelaskan bahwa terdapat perbedaan yang relatif mendasar antara Madura barat dan Madura timur, terutama dalam hal karakter geografisnya. Madura barat dikenal dengan tipe geografis yang relatif gersang. Sebaliknya, Madura timur dikenal dengan tekstur geografis yang lebih subur, khususnya di daerah ujung timur, yaitu Sumenep.

Meskipun secara geografis Huub de Jonge membagi Madura dalam dua kutub berbeda antara barat dan timur, hal tersebut tidak lantas mencerminkan adanya perbedaan bangunan sistem dan struktur sosialnya. Dalam beberapa hal, antara Madura barat dan Madura Timur memang memuat perbedaan. Secara umum, baik Madura barat maupun Madura timur memiliki konstruksi sosial yang sangat berdekatan bahkan nyaris sama. Sekurang-kurangnya,

\footnotetext{
${ }^{26}$ Huub de Jonge, Agama, Kebudayaan, dan Ekonomi: Studi Interdisipliner tentang Masyarakat Madura (Jakarta: Rajawali Press, 1989), 24.
} 
kesamaan keduanya ada pada dua aspek, yakni bangunan struktur sosial hirarkis dan kultur religiusitas yang sama-sama identik dengan penghormatan totalitas pada simbol dan lembaga keagamaan, seperti kiai dan pesantren. ${ }^{27}$

Sistem hirarki masyarakat Madura tergambar jelas terutama pada peribahasa lokal mereka, bhuppa' bhabbu' ghuru rato. Secara semantik, peribahasa tersebut bukan saja mengandung indiksikalitas makna standar kepatuhan, tetapi juga sistem jenjang sosial yang berlaku umum, baik di kehidupan domestik rumah tangga maupun publik. Sedangkan dalam aspek religiusitas, penghormatan totalitas masyarakat Madura terhadap unsur-unsur keagamaan tercermin jelas dari penghargaan dan pengagungan mereka terhadap nilai dan pranata keislaman, seperti kepada kiai dan pesantren. Baik kiai ataupun pesantren keduanya adalah simbol kebesaran agama dalam kehidupan masyarakat Madura. Tidak saja menjadi tempat di mana mereka mempelajari agama, pesantren (dalam hal ini kiai/pengasuh pesantren) juga merupakan sumber teladan kehidupan sehari-hari. Begitu tingginya kedudukan kiai dan pesantren dalam kultur masyarakat Madura, sehingga banyak kalangan menyebut keduanya sebagai miniatur raja dan kerajaan kecil di Madura. ${ }^{28}$

Perihal kehidupan sosial-keagamaan masyarakat Madura dapat dideskripsikan melalui beberapa hal berikut. Pertama, ketokohan kiai. Secara definitif dalam KBBI, "kiai" digunakan sebagai sebutan kepada ahli ilmu ('alim-'ulamā) agama Islam, guru ilmu gaib (dukun dan sebagainya); kepala distrik (di Kalimantan Selatan); dan sebutan bagi nama benda yang dianggap bertuah. ${ }^{29}$ Jika merujuk pada pemaknaan ini, maka kiai sejatinya memiliki pengertian yang beragam. Namun, dalam kajian ini, sebutan kiai lebih ditujukan kepada mereka para ahli ilmu agama Islam, atau tokoh agamawan Islam dengan wawasan keislaman yang luas dan mendalam.

Lebih spesifik, dalam konteks sosial-keagamaan masyarakat Madura, sebutan kiai merupakan status yang menunjuk setidaknya

\footnotetext{
27 Abd Hannan dan Kudrat Abdillah, "Hegemeni Religio Kekuasaan dan Transformasi Sosial: Mobilisasi Jaringan Kekuasaan dan Keagamaan Kyai dalan Dinamika Sosio-kultural Masyarakat”, Sosial Budaya, Vol. 16, No. 1 (2019), 10.

${ }^{28}$ Hannan, "Agama, Kekerasan, dan Kontestasi Politik Elektoral", 215.

29 Badan Pembinaan dan Pengembangan Bahasa, "KBBI Daring", https://kbbi.kemdikbud.go.id/entri/Kiai. Diakses pada 8 September 2019.
} 
pada tiga pengertian. Pertama, kiai adalah sosok pribadi yang mempunyai nilai dan kadar spiritual tinggi karena dianggap memiliki kedekatan dengan Tuhan alam semesta. Kiai dalam sosok ini merupakan status sosial yang merepresentasikan puncak spiritual tertinggi, di mana kiai dipandang dapat mengetahui segala kekuasaan dan keagungan Allah. Kedua, kiai adalah sebutan bagi mereka yang memiliki kedudukan sebagai pimpinan atau pengasuh lembaga keagamaan pesantren. Penyebutan kiai pada pimpinan pesantren secara langsung menafikan peran dan keberadaan tokoh keagamaan di luar dirinya, seperti kiai yang memiliki atau mengasuh sebuah surau (kiai langgar). Ketiga, kiai adalah sebutan bagi setiap orang yang memiliki perhatian besar terhadap hal-hal keagamaan..$^{30}$ Perhatian di sini dijalankan baik melalui kegiatan ceramah, mengajar, dan sekian aktivitas lain yang bersentuhan langsung dengan dakwah keagamaan Islam. Jika mendasarkan pada pengertian ini, maka setiap orang yang terlibat dalam pengajaran agama, dalam kultur masyarakat Madura disebut sebagai kiai, sekalipun hanya kiai langgar.

Kedua, ke-NU-an. Selain kepada kiai, penghormatan dan pengagungan dalam kultur sosial-keagamaan masyarakat Madura juga ditujukan pada keberadaan ormas Islam NU. Sebagaimana pengakuan mereka kepada kiai dan pesantren, penghormatan masyarakat Madura terhadap keberadaan NU pun begitu tinggi. Tingginya pengakuan terhadap NU ini tergambar jelas dalam anekdot keagamaan setempat. Ketika orang Madura ditanya tentang agamanya, maka secara langsung mereka akan menjawab "NU", bukan Islam. Hal ini mengisyaratkan bahwa dari sekian banyak ormas Islam, masyarakat Madura hanya mengenal NU. ${ }^{31}$ Sementara ormas lain seperti Muhammadiyah, Sarekat Islam (SI), dan sebagainya tidak begitu memperoleh tempat dalam tradisi dan kultur keislaman mereka.

Bagi masyarakat Madura, NU bukan saja merupakan organisasi atau tempat perkumpulan, tetapi lebih dari itu merupakan gerakan dakwah kelompok Islam tradisional yang diyakini telah memberi banyak sumbangsih besar terhadap penyebaran Islam di tanah Madura. Dalam tradisi keislaman keagamaan masyarakat,

\footnotetext{
${ }^{30}$ Endang Turmudi, Perselingkuhan Kiai dan Kekuasaan (Yogyakarta: LKiS, 2004), 29.

${ }^{31}$ Hannan, “Agama, Kekerasan, dan Kontestasi Politik Elektoral”, 34.
} 
keberadaan NU tidak ubahnya gerak nadi yang mengalirkan darah spirit keislaman mereka. Hal ini dapat menjelaskan mengapa masyarakat Madura memiliki ciri khas ritual keagamaan yang tradisional, seperti yang juga banyak ditemui di pulau Jawa pada umumnya. Demikian pula, hampir bisa dikatakan bahwa seluruh pesantren di Madura memiliki afiliasi dengan NU, sehingga tradisi Islam yang berkembang di lingkungan pesantren Madura sangat kental dengan nuansa ke-NU-an. Alhasil, baik pesantren, kiai, dan NU, ketiganya merupakan ruang dan lembaga keislaman tradisional, di mana kultur sosial-keagamaan masyarakat Madura diproduksi dan direproduksi.

Ketiga, ritual keagamaan. Ritual keagamaan masyarakat Madura memiliki corak tradisional yang menunjukkan kemiripan dengan kegiatan keagamaan yang ada di pulau Jawa pada umumnya, seperti nyekar, tablilan, selametan, peringatan 100 hari kematian, 1000 hari, dan sebagainya. Di beberapa daerah, terutama di daerah kepulauan Sumenep, ritual keagamaan masyarakat masih mengikuti ritualritual terdahulu, seperti rokat tase', saroningan, dan sekian ritual keagamaan lainnya yang pernah ada pada masa kejayaan HinduBuddha dahulu. ${ }^{32}$

Hal menarik dalam aktivitas keagamaan masyarakat Madura adalah hubungan kiai dengan ritual keagamaan ini. Hampir tidak pernah ada aktivitas atau kegiatan ritual keagamaan masyarakat Madura yang tidak melibatkan kehadiran kiai. Tanpa kehadiran dan keikutsertaan seorang kiai, sebuah bajatan atau kegiatan ritual keagamaan tertentu tidak akan dilaksanakan. Kiai berkedudukan sebagai elemen vital yang menentukan berlangsung-tidaknya sebuah kegiatan ritual keagamaan. Dalam hal ini, kiai adalah representasi kesempurnaan ritual. Melalui daya kharisma, kewibawaan, dan tingkat religiusitas kiai, masyarakat Madura meyakini bahwa sebuah hajatan atau ritual kegamaan akan lebih bernilai dan diterima oleh Tuhan semesta. Kenyataan ini semakin menguatkan sentralitas status sosial kiai dalam kultur sosialkeagamaan masyarakat Madura.

${ }^{32}$ Hannan, "Fanatisme Komunitas Pesantren”, 245. 
Keempat, pesantren. Dalam KBBI, "pesantren” dimaknai dengan asrama dan tempat murid-murid belajar mengaji; pondok. ${ }^{33}$ Dalam kultur masyarakat Madura, pesantren populer dengan sebutan pondhuk (pondok) yang berarti rumah untuk sementara waktu, madrasah, atau asrama tempat mengaji Islam dan segala sesuatu yang berhubungan dengannya. Pada umumnya, sekurangkurangnya pesantren terdiri dari tiga struktur, yakni kiai, santri, dan masjid atau langgar. Kiai merujuk pada pimpinan pesantren sebagai pengendali segala bentuk kebijakan pesantren. Sedangkan santri adalah mereka yang belajar di pesantren. Secara tipologis, santri dibagi menjadi dua, yaitu santri mukim atau yang tinggal di asrama pesantren dan santri kalong atau yang tidak menetap di asrama. Sedangkan surau adalah tempat utama pesantren; ruang di mana aktivitas pesantren dijalankan, mulai dari salat jamaah, kajian keagamaan, salawatan, dan sebagainya.

Pada umumnya, kultur pembelajaran pesantren Madura dilakukan secara beragam, ada yang masih mengandalkan pola tradisional dengan sistem sorogan, dan ada pula yang sudah menerapkan sistem modern seperti sekolah berjenjang. Di luar keduanya, terdapat juga pesntren yang berusaha memadukan kedua model pembelajaran tersebut. Namun demikian, terlepas dari keanekaragaman sistem pembelajaran tersebut, fokus pembelajaran di lingkungan pesantren Madura adalah tentang keislaman yang meliputi pengenalan, pemahaman, dan penguatan ajaran abl alSunnah wa al-Jamāab lewat kajian kitab kuning klasik dalam berbagai bidang, seperti tauhid, fiqh, tajwid, dan sebagainya. Dalam kehidupan masyarakat Madura, pesantren memainkan peran dan fungsi yang tidak saja fundamental, tetapi juga terbilang strategis yang meliputi segala aspek sosial, khususnya dalam hal pengembangan dan pembentukan corak dan warna Islam di daerah setempat.

\section{Pesantren sebagai Salah Satu Kearifan Lokal Masyarakat Madura}

Meminjam bahasa Madjid, pesantren merupakan bangunan sistem nilai dan norma sosial-keagamaan yang tergolong indigenous. Berdasarkan hal tersebut, pesantren tidak hanya identik dengan

33 Badan Pengembangan dan Pembinaan Bahasa, "KBBI Daring", https://kbbi.kembdikbud.go.id/entri/Pesantren. Diakses pada 8 September 2019. 
lembaga keagamaan, tetapi juga memiliki watak keaslian kebudayaan suatu daerah seperti Madura. $^{34}$ Sebagai lembaga keagamaan, pesantren dalam kultur masyarakat Madura berfungsi besar sebagai ruang pembelajaran keagamaan sekaligus ruang pembinaan mental spiritual. Sebagai salah satu produk realitas kedaerahan, pesantren memainkan peran dalam hal menjaga karakter lokalitas kedaerahan. Secara umum, keunggulan dan kelebihan pesantren Madura terletak pada kemampuannya mengompromikan Islam dan budaya lokal tanpa menimbulkan konfrontasi dan pertentangan antarkeduanya.

Secara sosiologis, menyebut pesantren sebagai salah satu corong kearifan lokal masyarakat Madura tidaklah berlebihan, mengingat konstruksi sosial-keagamaan masyarakat Madura sendiri sejauh ini identik, diproduksi, dan direproduksi dari dan oleh pesantren. Pesantren dapat ditemukan hampir di semua wilayah Madura, yang masing-masing memiliki jaringan kuat dan luas, baik melalui jaringan santri, alumni, masyarakat atau simpatisan, keluarga besar kiai, hingga lembaga-lembaga lain yang tersebar di banyak penjuru. Kuatnya eksistensi dan pengaruh pesantren di lingkungan masyarakat Madura berbanding lurus dengan peta sebarannya yang hampir merata, mulai dari wilayah-wilayah urban hingga pedalaman, dan mulai dari pesantren besar hingga pesanren kecil sekalipun. Di Kabupaten Pamekasan, misalnya, berdasarkan data terbaru dari Departemen Agama Pamekasan, terdapat 185 pesantren dengan total 59.323 santri yang tersebar di seluruh kecamatan dan desa. Angka ini akan jauh bertambah besar jika digabungkan dengan jumlah pesantren yang ada di tiga kabupaten lainnya di Madura, yaitu Sumenep, Sampang, dan Bangkalan. Adapun rincian peta sebaran sekaligus jumlah pesantren di Kabupaten Pamekasan, secara keseluruhan dapat dilihat pada tabel berikut:

Tabel 1:

Jumlah Pondok Pesantren dan Santri Menurut Kecamatan di Kabupaten Pamekasan 2018

\begin{tabular}{|c|l|c|c|}
\hline No & \multicolumn{1}{|c|}{ Kecamatan } & $\begin{array}{c}\text { Jumlah } \\
\text { Pesantren }\end{array}$ & $\begin{array}{c}\text { Jumlah } \\
\text { Santri }\end{array}$ \\
\hline 1 & Tlanakan & 11 & 2.109 \\
\hline 2 & Pademawu & 5 & 688 \\
\hline
\end{tabular}

${ }^{34}$ Madjid, Bilik-Bilik Pesantren, 3. 


\begin{tabular}{|c|l|c|c|}
\hline 3 & Galis & 2 & 93 \\
\hline 4 & Larangan & 19 & 3.625 \\
\hline 5 & Pamekasan & 11 & 4.394 \\
\hline 6 & Proppo & 10 & 5.54 \\
\hline 7 & Palengaan & 29 & 25.012 \\
\hline 8 & Pegantenan & 24 & 2.422 \\
\hline 9 & Kadur & 20 & 5.585 \\
\hline 10 & Pakong & 11 & 3.481 \\
\hline 11 & Waru & 8 & 2.353 \\
\hline 12 & Batu Marmar & 19 & 3.274 \\
\hline 13 & Pasean & 16 & 1.233 \\
\hline \multicolumn{2}{|c|}{ Total } & 185 & 59.323 \\
\hline
\end{tabular}

Sumber: Kantor Departemen Agama Kabupaten Pamekasan

Dengan mengacu pada kondisi di atas, bisa dipahami jika banyak kalangan menyebut pesantren sebagai corong kearifan lokal yang dalam kenyataannya memiliki peran, fungsi, dan pengaruh besar terhadap bangunan sistem dan struktur sosial masyarakat Madura. Pengaruh tersebut tampak tidak dalam aspek keagamaan an sich, tetapi juga pada apsek-aspek lainnya, seperti kebudayaan, ekonomi, pendidikan, politik, dan sebagainya.

\section{Kearifan Lokal Pesantren sebagai Bangunan Moderasi Islam Masyarakat Madura}

Sekurang-kurangnya terdapat tiga alasan utama mengapa pesantren, dalam kedudukannya sebagai salah satu corong sekaligus benteng kearifan lokal keagamaan masyarakat Madura, sejauh ini dapat memainkan peran dan fungsi sentral dalam mewujudkan dan menjaga bangunan moderasi Islam di kalangan masyarakat setempat. Pertama, konsep Islam moderat secara definitif senantiasa disandingkan dengan konsep wasatīyah (jalan tengah).$^{35}$ Konsep wasatiyah sendiri mengandung arti perilaku atau sikap keagamaan yang memilih jalan moderat; satu karakter keislaman yang tidak condong ke golongan kanan (Islam tekstualnormatif) maupun kiri (Islam liberal). Jika ditarik ke dalam terminologi Giddens, Islam wasatiyah adalah Islam yang berusaha menengahi dua kutub ekstrem antara kelompok liberal dan Islam tekstual-normatif. Dalam konteks keislaman Indonesia, karakter

${ }^{35}$ Hilmy, "Quo-Vadis Islam Moderat”, 262. 
Islam yang demikian itu, untuk beberapa alasan, teridentifikasi pada salah satu ormas besar Islam, yaitu NU.

Secara kultural, mayoritas pesantren di Madura berafiliasi pada NU. Sebagaimana termaktub dalam Anggaran Dasarnya, NU menekankan pada beberapa prinsip yang dipercaya berkesesuaian dengan spirit moderasi Islam, yaitu al-'adālah (keadilan), al-tawassut (moderasi), al-tawāaun (keseimbangan), dan al-tasāmuh (toleransi). ${ }^{36}$ Dengan dmikian, kedekatan pesantren pada NU sedikit banyak menyisakan pengaruh moderasi Islam terhadap keseluruhan tradisi keagamaan yang diajarkan di pesantren, baik yang sifatnya konseptual hingga pada tataran praktis keagamaan sehari-hari seperti ritual keagamaan yang dipraktikkan di pesantren. Pada tataran konseptual, moderasi Islam di lingkungan pesantren Madura diajarkan lewat kajian keagamaan yang senantiasa berhaluan abl al-Sunnah wa al-Jamäah. Selain berpegang teguh pada dua sumber otoritatif Islam, al-Qur'ān dan Ḥadìth, tradisi keilmuan pesantren turut diproduksi dari pemikiran para ulama salaf al-sălih, baik berupa Ijmā’ maupun Qiyās. Kultur pembelajaran demikian memiliki pengaruh yang kuat pada proses pembentukan karakter moderasi keagamaan pesantren. Di satu sisi, mereka dapat melepaskan diri dari kungkungan keagamaan tekstual dan normatif, dan di sisi lain dapat memproduksi paradigma keagamaan yang universal dan lentur. Hal tersebut tentu memiliki konsekuensi langsung pada tataran praktisnya. Relasi pesantren dan NU di Madura memungkinkan amaliah-amaliah populer NU, yang sarat nilai moderatisme, diterapkan di lingkungan pesantren.

Kedua, sebagaimana kedekatannya dengan NU, salah satu ormas penyokong paradigma keagamaan tradisional, pesantren memiliki perhatian cukup besar terhadap berbagai bentuk ritual keagamaan yang bernuansa lokal atau tradisional. Secara definitif, ritual berarti berkaitan dengan ritus, yaitu tata cara dalam upacaya keagamaan. ${ }^{37}$ Beberapa ritual keagamaan yang dimaksud adalah seperti salawatan, nyekar, tablilan, bersanjih, koloman, pengajian langgar, dan slametan untuk memperingati hari-hari tertentu seperti ritual hawl dan sejenisnya. Mengentalnya tradisionalisme Islam di

36 Anggaran Dasar Nahdlatul Ulama 2010 dalam Tim Penyusun, Keputusan Muktamar XXXII Nabdlatul Ulama (Jakarta: Sekretariat PBNU, 2010), 20.

37 Badan Pengembangan dan Pembinaan Bahasa, "KBBI Daring", https://kbbi.kemdikbud.go.id/entri/Ritus. Diakses pada 31 Desember 2019. 
lingkungan pesantren secara umum, pada batasan-batasan tertentu mengandung konsekuensi atas tumbuhnya mentalitas keagamaan masyarakat pesantren yang cenderung terbuka dan membuka diri terhadap segala aspek kreativitas lokal, seperti adat dan tradisi. Kenyataan ini memberikan penjelasan bagaimana pesantren memiliki kedekatan pada realitas keragaman lintas aspek, sehingga pesantren cukup familiar dengan, bahkan turut mengembangkan akan, konsep toleransi, pluralitas, hak asasi manusia, dan sebagainya.

Selain itu, besarnya perhatian pesantren Madura terhadap berbagai kreativitas keagamaan lokal ini pada titik tertentu memberikan nilai lebih bagi upaya adaptasi pesantren dengan lingkungan sekitarnya. Hal tersebut pada gilirannya membuat kehadiran pesantren mudah diterima oleh, bahkan menyatu dengan, masyarakat. Alhasil, pesantren dalam kehidupan masyarakat Madura menjadi lembaga multifungsi dan panutan, bukan saja dalam bidang keagamaan, tetapi juga dalam bidang sosial lainnya seperti pendidikan, budaya, ekonomi, hingga politik.

Ketiga, fakta bahwa pesantren mampu menularkan pengaruh cukup kuat dalam proses keberlangsungan sistem dan struktur budaya masyarakat Madura tidak bisa dilepaskan dari keberadaan sosok kiai. Kiai adalah simbol keagamaan sekaligus simbol kekuasaan. Kiai sebagai simbol keagamaan mengandaikan kehadiran pribadi yang mempunyai derajat religiusitas tinggi dan kharismatik. Sementara kiai sebagai simbol kekuasaan merujuk pada kedudukannya sebagai kelas elite sosial dalam bangunan hirarki masyarakat Madura. Hal tersebut, menurut Hannan, menjadikan kiai sebagai kelas sosial yang senantiasa menjadi pembenaran, benar, dan dibenarkan. ${ }^{38}$

Dalam kultur keagamaan masyarakat Madura, kiai identik dengan pesantren. Antara kiai dan pesantren adalah satu kesatuan yang tidak dapat dipisahkan. Jika dalam pandangan masyarakat Madura pesantren dianggap sebagai representasi kerajaan kecil, maka kiai adalah sosok raja kecil, pemegang otoritas tunggal yang menentukan segala bentuk kebijakan pesantren. Menurut kenyataan ini, kiai bukan semata identitas atau penanda atas keagungan agama dan kedalaman religiusitas, tetapi lebih dari itu ia merupakan simbol kelas sosial tertinggi dalam hirarki masyarakat

${ }^{38}$ Hannan, "Fanatisme Komunitas Pesantren”, 256. 
Madura. Dalam perspektif Giddens, pesantren merupakan representasi pendidikan keagamaan yang mengemban peran dan fungsi sebagai strukturisasi keagamaan. Sedangkan kiai adalah representasi simbol kelas sosial yang memiliki peran dan fungsi strategis sebagai agen keagamaan. ${ }^{39}$ Dalam kedudukannya yang starategis ini, baik kiai maupun pesantren memiliki peran cukup sentral untuk memproduksi dan mereproduksi berbagai sistem sosial, termsuk di dalamnya menciptakan moderasi Islam di tengah masyarakat Madura.

Jika merujuk pada sekian kenyataan di atas, eksistensi pesantren dan kiai dalam dinamika keagamaan masyarakat Madura, selain dapat dilihat sebagai hubungan agen dan struktur nilai keislaman lokal, pun juga dapat dilihat sebagai suatu bangunan kearifan lokal yang mencerminkan tipologi keagamaan masyarakat setempat. Secara sosiologis, kearifan lokal dalam hubungan antara kiai dan pesantren tercermin jelas dalam tradisi masyarakat Madura yang memiliki penghormatan cukup besar terhadap keduanya. Meminjam istilah Berger, ${ }^{40}$ kiai dan pesantren adalah representasi trialektika nilai yang memproduksi realitas keagamaan; sebuah proses internalisasai dan eksternalisasi nilai yang bermuara pada terbentuknya objektivikasi Islam lokal, yaitu Islam yang mengusung nilai-nilai moderat dan memiliki kemampuan beradaptasi di tengah keanekaragaman budaya, adat, dan tradisi masyarakat Madura secara keseluruhan.

\section{Penutup}

Sistem dan struktur sosial masyarakat Madura turut dibentuk salah satunya oleh eksistensi kreativitas lokal yang berpadu dengan religiusitas. Masyarakat Madura memiliki sistem dan struktur sosial yang mempunyai penghormatan dan pengakuan cukup besar terhadap simbol maupun tokoh keagamaan. Pesantren sebagai lembaga pendidikan keagamaan tradisional pada perkembangannya merupakan satu dari sekian banyak lambang keagamaan Islam yang selama ini banyak memengaruhi bangunan kebudayaan masyarakat Madura. Bangunan keislaman pesantren dipercaya meliputi karakter moderasi Islam, yaitu satu ciri khas keislaman yang

\footnotetext{
39 Anthony Giddens, The Third Ways: Jalan Ketiga Pembaruan Demokrasi (Jakarta: Gramedia Pustaka Utama, 2000), 23.

40 Peter L. Berger dan Thomas Luckmann, Tafsir Sosial atas Kenyataan; Risalab tentang Sosiologi Pengetahuan (Jakarta: PT Pustaka LP3S, 2013), 45.
} 
menjunjung tinggi sikap dan ide-ide moderatisme, seperti toleransi, inklusivitas, dan pluralitas. Moderasi keislaman sebagai produk kearifan lokal pesantren di Madura terutama diupayakan melalui kemampuan pesantren dalam memainkan peran ganda, yakni peran keagamaan di satu sisi, dan peran sebagai agen perubahan sosial di sisi yang lain.

Pesantren sebagai wahana moderasi Islam dalam masyarakat Madura dapat ditelusuri pada tiga aspek. Pertama, afiliasinya dengan NU, ormas yang sejauh ini dianggap sebagai miniatur moderasi Islam di Indonesia. Kedekatan pesantren dengan NU menyisakan warna tersendiri bagi kultur keislaman masyarakat Madura. Hal itu terutama tempampang jelas dalam bangunan sistem keagamaan pesantren yang mengusung empat prinsip NU, yakni al-'adälah (keadilan), al-tawassut (moderasi), al-tawäzun (keseimbangan), dan altasämuh (toleransi). Kedua, ritual keagamaan pesantren yang identik dengan kreativitas lokal. Klaim bahwa pesantren sebagai penyemai benih moderasi Islam di Madura diperkuat oleh konstruksi keagamaan pesantren yang lekat dengan realitas keaslian daerah. Konstruksi tersebut dapat dilihat pada aktivitas kegamaan pesantren seperti salawatan, tablilan, bersenjih, manaqiban, metode pengajaran soroghan, kajian kitab kuning, dan sejenisnya. Ketiga, kultur hirarki pesantren yang menekankan penghormatan dan pengakuan yang tinggi terhadap keberadaan kiai. Di lingkungan pesantren Madura, kiai bukan semata simbol bagi kedalaman pengetahuan maupun religiusitas dalam beragama. Lebih dari itu, kiai adalah produk kearifan lokal yang berperan sangat penting dalam memproduksi dan mereproduksi bangunan moderasi Islam di Madura.

\section{Daftar Rujukan}

Abdullah, Said. Pesantren; Jati Diri dan Pencerahan Masyarakat, Cet. I. Sumenep: Said Abdullah Istitute Publishing, 2010.

Abdurrohman, Asep. "Eksistensi Islam Moderat dalam Perspektif Islam", Rausyan Fikr, Vol. 14, No. 1, 2018.

Arafah, Nur. "Pengetahuan Lokal Suku Moronene dalam Sistem Pertanian di Sulawesi Tenggara". Tesis--Institut Pertanian Bogor, 2002.

Badan Pengembangan dan Pembinaan Bahasa Kembdikbud. "KBBI Daring", https://kbbi.kemdikbud.go.id. 
Berger, Peter L. dan Thomas Luckmann. Tafsir Sosial atas Kenyataan; Risalah tentang Sosiologi Pengetahuan. Jakarta: PT Pustaka LP3S, 2013.

De Jonge, Huub. Agama, Kebudayaan, dan Ekonomi: Studi Interdisipliner tentang Masyarakat Madura. Jakarta: Rajawali Press, 1989.

Departemen Pendidikan dan Kebudayaan. Kamus Besar Bahasa Indonesia, Cet. 2. Balai Pustaka: Jakarta, 1999.

Dharmawan, Arya Hadi. "Kearifan Lokal dalam Sistem Sosial Ekonomi Masyarakat Penenun Bugis-Wajo", Mudra, Vol. 28, No. 2, 2013.

Giddens, Anthony. The Third Ways: Jalan Ketiga Pembaruan Demokrasi. Jakarta: Gramedia Pustaka Utama, 2000.

Hannan, Abd dan Kudrat Abdillah. "Hegemeni Religio Kekuasaan dan Transformasi Sosial: Mobilisasi Jaringan Kekuasaan dan Keagamaan Kyai dalan Dinamika Sosio-kultural Masyarakat", Sosial Budaya, Vol. 16, No. 1, 2019.

----. "Agama, Kekerasan, dan Kontestasi Politik Elektoral: Penggunaan Simbol Keagamaan Kiai dan Kekuasaan Blater dalam Pertarungan Politik Lokal Madura", Jurnal Sosiologi Agama, Vol. 12, No. 2, 2018.

-----. "Fanatisme Komunitas Pesantren NU Miftahul Ulum dan Stigma Sosial pada Muhammadiyah di Kabupaten Pamekasan". Tesis-- Universitas Airlangga Surabaya, 2017.

Hayati, Beti Nur dan Muhammad Arif Fahrudin Alfana.

"Kebijakan Kependudukan di Kabupaten Sleman Pascaberakhirnya MDGS", Natapraja: Jurnal Kajian Ilmu Administrasi Negara, Vol. 4, No. 2 , 2016.

Hidayati, Tatik. "Perempuan Madura antara Tradisi dan Industrialisasi", Karsa, Vol. 16, No. 2, 2009.

Hilmy, Masdar. "Quo-Vadis Islam Moderat Indonesia?: Menimbang Kembali Modernisme Nahdlatul Ulama dan Muhammadiyah", Miqot: Jurnal Ilmu-ilmu Keislaman, Vol. 37, No. 2, 2012.

Khan, M.A. Muqtedar. "Islamic Democracy and Moderate Muslims: The Straight Path Runs through the Middle", American Journal of Islamic Social Sciences, Vol. 22, No. 3, 2005. 
Kuntowijoyo. Perubahan Sosial dalam Masyarakat Agraris Madura 1850-1940, terj. Mahmoed Effendhie. Yogyakarta: Mata Bangsa, 2002.

Madjid, Nurcholish. Bilik-Bilik Pesantren; Sebuah Potret Perjalanan, Cet. I. Jakarta: PT. Dian Rakyat, 1997.

Rozaki, Abdur. Menabur Kharisma Menuai Kuasa; Kiprah Kiai dan

Blater sebagai Rezim Kembar di Madura. Yogyakarta: Pustaka Marwa, 2004.

Rusli. "Gagasan Khaled Abu Fadl tentang Islam Moderat versus Islam Puritan: Perspektif Sosiologi Pengetahuan", Ilmu Ushuluddin, Vol. 8, No. 1, 2009.

Sadik, A. Sulaiman. "Kearifan Lokal dalam Sastra Madura dan Aplikasinya dalam Kehidupan Sehari-Hari," Okara: Jurnal Bahasa dan Sastra, Vol. 1, No. 6, 2011.

Salam, Moh. Ishaq Abd. "Reproduksi Kekuasaan Kiai; Penggunaan Sarana Ideologi dan Kekuasaan dalam Pemilukada Bangkalan". Tesis--Universitas Airlangga Surabaya, 2015.

Sartini. "Menggali Kearifan Lokal Nusantara: Sebuah Kajian Filsafati”, Jurnal Filsafat, Vol. 14, No. 2, 2004.

Tim Penyusun. Keputusan Muktamar XXXII Nabdlatul Ulama. Jakarta: Sekretariat PBNU, 2010.

Tim Penyusun. Oxford Advanced Learner's Dictionary. Oxford: Oxford University Press, 1994.

Turmudi, Endang. Perselingkuban Kiai dan Kekuasaan. Yogyakarta: LKiS, 2004.

Wehr, Hans. Modern Written Arabic. Gottingen: Otto Harrassowitz Verlag, 1979.

Wiratha, I Made. Metodologi Penetilian Sosial Ekonomi. Yogyakarta: CV. Andi Offset, 2006. 